\title{
Uptake and acceptability of assisted and unassisted HIV self-testing among men who purchase sex in brothels in Indonesia: a pilot intervention study
}

\author{
Luh Putu Lila Wulandari, ${ }^{1,2^{*}}$, John Kaldor ${ }^{1}$ and Rebecca Guy ${ }^{1}$
}

\begin{abstract}
Background: Along with sexual partners of other high-risk groups, men who purchase sex (MWPS) represented 18\% of new HIV diagnoses worldwide in 2018. They are therefore an important population for HIV prevention globally. Despite very low HIV testing coverage among MWPS in many countries, the role of HIV self-testing to increase testing coverage has not been explored. We, therefore, conducted a pilot intervention study to evaluate the uptake and acceptability of assisted and unassisted HIV self-testing among MWPS in Indonesia.

Methods: MWPS attending seven brothels in Bali between December 2017 and January 2018 were recruited by lay health providers to participate in a brief health survey, and then invited to have a HIV self-test (assisted or unassisted) with an OraQuick ${ }^{\circledR}$ ADVANCE Rapid HIV-1/2 Antibody Test and complete a post-test acceptability survey.

Results: A total of 292 men completed the health survey (response rate: 70\%) and 188 (64.6\%) accepted HIV selftesting. Of these men, 13.3\% had ever tested for HIV and 58.9\% reported condom use at their last sexual encounter with a brothel-based female sex worker. Nearly all men (98.9\%) who accepted a HIV self-test preferred assisted HIV self-testing - of whom $83.9 \%$ preferred to be fully assisted and $16.1 \%$ opted to be partially assisted and read their results privately. Of the men who accepted the test and showed the result to the lay health providers, 4 (2.1\%) received reactive results. Linkage following HIV self-test is a concern, as none of the four men with a reactive result attended HIV testing at the recommended referral HIV testing clinic over a two-month follow-up period.

Conclusions: This study is the first to investigate the acceptance of HIV self-testing when offered to MWPS in brothels by lay health providers. The high uptake of HIV self-testing suggests that this testing model is acceptable and could increase the very low HIV testing coverage among MWPS. The strong preference for fully assisted HIV self-testing highlights the importance of involving lay health providers in future testing programs. When scaling up HIV self-testing programmatically, strategies to improve linkage-to-care should be considered and evaluated.
\end{abstract}

Keywords: HIV testing, HIV self-testing, Men who purchase sex, Clients of sex workers, Scale-up, Lay workers, Indonesia

\footnotetext{
* Correspondence: Iwulandari@kirby.unsw.edu.au; putuwulandari@gmail.com

${ }^{1}$ The Kirby Institute, University of New South Wales, Level 6 Wallace Wurth

Building, UNSW Kensington Campus, Sydney, NSW 2052, Australia

${ }^{2}$ Department of Public Health and Preventive Medicine, Faculty of Medicine,

Udayana University, Denpasar, Indonesia
}

(c) The Author(s). 2020 Open Access This article is licensed under a Creative Commons Attribution 4.0 International License, which permits use, sharing, adaptation, distribution and reproduction in any medium or format, as long as you give appropriate credit to the original author(s) and the source, provide a link to the Creative Commons licence, and indicate if changes were made. The images or other third party material in this article are included in the article's Creative Commons licence, unless indicated otherwise in a credit line to the material. If material is not included in the article's Creative Commons licence and your intended use is not permitted by statutory regulation or exceeds the permitted use, you will need to obtain permission directly from the copyright holder. To view a copy of this licence, visit http://creativecommons.org/licenses/by/4.0/ The Creative Commons Public Domain Dedication waiver (http://creativecommons.org/publicdomain/zero/1.0/) applies to the data made available in this article, unless otherwise stated in a credit line to the data. 


\section{Background}

In 2006, it was estimated that between 9 and $10 \%$ of the male population in many regions globally had purchased sex in the last 12 months [1]. Men who purchase sex (MWPS) are considered to be a key population for HIV prevention because of their increased risk of HIV acquisition through sexual contact with female sex workers (FSWs), who have elevated infection rates in a number of countries [2, 3], with global data in 2018 revealed that FSWs have 21 times higher risk of acquiring HIV than adults aged 15-49 in population [4]. Around 18\% new reported HIV cases in almost all regions globally in 2018 were among MWPS and sexual partners of high-risk groups [5]. Several studies have shown higher HIV prevalence among MWPS than among corresponding male populations [6-15]. Furthermore, in many Asian countries, MWPS represent the largest single population at elevated risk of HIV [16]. Also, many MWPS have non-sex worker partners (wives, girlfriends) [17, 18], so there is potential for onward HIV transmission.

There is increasing focus globally on HIV treatment as prevention among key populations, based on studies showing both strong individual-level and public health benefits [19-21]. HIV treatment reduces the risk of onward HIV transmission to effectively zero [21, 22] and the risk of morbidity and mortality for people [20]. UNAIDS has set a target of $90 \%$ of people living with HIV being aware of their infection status [23, 24]. In response, in 2015, the World Health Organization (WHO) released guidelines recommending lay providers or community health workers should provide HIV testing services to those unable or reluctant to seek facility-based HIV testing [25] and HIV self-testing as an additional approach to HIV testing [26], reflecting accumulating evidence on the impact, acceptability and costeffectiveness of this strategy [27-34]. HIV self-testing offers promise due to its practicality, convenience, noninvasive, private and confidential nature [28, 35, 36]; and has the potential to overcome barriers associated with conventional, clinic-based HIV testing such as distance and stigma [37-39]. HIV self-tests could be particularly beneficial for populations, such as MWPS, who will generally conceal their sexual activity as it places them at risk of stigma or even legal sanctions [40, 41].

In Indonesia, with a HIV prevalence among the male adult population aged $15-49$ years of $0.5 \%$ in 2018 [42], a modelling study estimated that in 2016 there were 5.2 million MWPS [43], who had transactional sex with around 227 thousand FSWs [43], 8\% of whom were living with HIV [44]. Yet, surveys have found less than $10 \%$ of MWPS in Indonesia have ever been tested for HIV $[45,46]$. In Indonesia, HIV testing can be accessed through Voluntary Counselling and Testing (VCT) services at community health services, private clinics, or public and private hospitals. As of 2019, there were at least 6924 VCT services which reported testing activity to the Ministry of Health [47]. Recent qualitative research conducted among MWPS in Indonesia, however, identified a range of barriers to accessing traditional HIV testing modalities including embarrassment in asking for a test or being seen at the VCT clinic, fear of the invasive test, and inconvenience in terms of time and distance to the clinic $[37,48]$. The interviews also revealed a strong interest in HIV self-tests to overcome these barriers [37, 48].

Despite the call to introduce HIV self-tests to improve HIV testing coverage in key populations $[25,26]$, there have been no demonstration projects among MWPS particularly when HIV self-testing is offered by lay health providers at brothels. There have been numerous studies of HIV self-testing conducted among other risk and marginalised populations such as FSWs [49-51] and men who have sex with men $[52,53]$, but findings from these key populations cannot be applied to MWPS. Further, only a few studies have compared unassisted with assisted or supervised HIV self-testing [54-58] to allow for the identification of strategy which is preferable. In this study, we evaluated the acceptance of assisted and unassisted HIV self-testing when offered to MWPS in brothels in Indonesia by lay health providers.

\section{Methods \\ Study design}

We conducted a pilot intervention study of HIV selftesting among MWPS at brothels in Bali from 1 December 2017 to 31 January 2018. The CONSORT 2010 checklist of information to include when reporting a pilot or feasibility trial was used to guide the development of this report [59].

\section{Setting}

Bali has the sixth-highest HIV cases reported to the Ministry of Health from January to March 2019 in Indonesia [60]. All seven brothels in Denpasar Bali, often called complexes and recognized by health officials as operating in the area, and have been involved in previous HIV interventions targeting FSWs, were selected for the study. Brothels were located in complexes, with each brothel managed by a manager or pimp (a person who arranges the sex transaction with the potential clients and take a portion of the clients' payments). The number of FSWs in each complex varies according to the size of the brothel but ranges from 12 to 155 [61].

\section{Recruitment}

Participants were recruited by ten lay providers/workers from Yayasan Kerti Praja (YKP), a non-government organization (NGO) providing HIV clinical and 
prevention services to FSWs [62]. The lay workers' age ranged from 20 to 40 years old. Most of them have been working with the NGO for more than five years, have been conducting various HIV outreach activities at brothel settings, and have been trained on various HIV capacity building activities, including intensive VCT counsellor training. The ten lay providers (six men and four women) involved in the study worked alone in each brothel selected at a given time.

MWPS can also include men who pay for sex with men/transgender people, but this paper only considers those who pay for sex with women or FSWs because the recruitment location was brothels where FSWs see their male clients. The men were first invited to participate in a brief health survey and then invited to have a HIV selftest and complete a post-test acceptability survey. The lay workers received training in the study procedures and conducting the HIV self-test. During the study period, they approached all men who were waiting in the brothel areas and asked if they would be willing to participate in a health survey. The lay workers were stationed in the brothels every day during the study period for about eight hours, from $11 \mathrm{am}$ to $1 \mathrm{am}$. There were no posters or resources about HIV self-test displayed at the brothels.

The flowchart of the study procedure can be seen in Fig. 1. Those who were willing to participate in the health survey were provided with the first informed consent prior to the survey. Once the men completed the health survey, men were offered a HIV self-test. If they agreed to participate in the HIV self-test procedure, they would be provided with the second informed consent. Finally, they would complete the post-test survey once they completed the HIV self-test procedure.

\section{Eligibility and consent}

Men were eligible to participate in the health survey if they were: older than 18, had ever had sexual contact with FSWs, were able to communicate in Bahasa Indonesia, and were willing to provide written informed consent.

\section{Health survey}

To improve the response rate, the health survey was introduced to clients not as specifically focused on HIV. However, the lay workers explained that the survey included questions around socio-demographic, sexual behaviours and HIV testing history. The questions were asked by the lay workers, and the interview took about 5-10 min. The decision to use an intervieweradministered, rather than a self-completed questionnaire, was based on lower education levels of the participants ascertained in a previous survey [45].

\section{HIV self-test}

Following the health survey, men were offered a HIV self-test. For those who agreed, the lay workers explained and demonstrated how to perform the test and interpret the results, and men were offered assisted or unassisted HIV self-testing. Assisted HIV self-testing had two options: 1) Fully assisted: lay workers supervised the men while they conducted the HIV self-test onsite and interpreted the results; or 2) Partially assisted: men would conduct the HIV self-test onsite with lay workers' supervision and interpret the result independently, but could choose to show the results to the lay worker. Unassisted HIV self-testing involved men taking the kit and performing the test offsite; and if they were willing to show the results to the lay workers, the men were asked to return the used test kit in a sealed envelope to the YKP, or take the picture of the used test kit and send it to the lay worker through text message. These multiple options were offered as qualitative research in this setting had revealed that concerns about confidentiality and embarrassment were key barriers to HIV testing [37, 48]. For partially assisted testers, there was a place at each brothel where the clients can perform the test in private. Depending on clients' preferences, they would use their own mobile phones or watches as timekeeper, or the lay workers reminded them when it was the time to read the test result.

The OraQuick ${ }^{\ominus}$ ADVANCE Rapid HIV-1/2 Antibody Test (OraQuick; OraSure Technologies, Inc., Bethlehem, PA) HIV self-test kit was used in the study. HIV self-test procedures were in accordance with the manufacturer's instructions, which was translated into Bahasa Indonesia. For men with reactive HIV self-test results and disclosed their results to the lay workers, the lay workers would then hold a post-test counselling session, providing the men with information on HIV and HIV testing, as what the lay workers usually perform at the VCT clinic for HIV positive clients. Regardless of the results, each participant was given information about the availability of free HIV testing at the YKP clinic. Men were advised to attend the YKP clinic to confirm the result with standard rapid testing procedure with further assessment, HIV treatment and support as needed. Men could also attend other clinics if they preferred. All the used kits were stored in a box and put at the YKP clinic.

\section{Post-test acceptability survey}

A post-test acceptability survey was conducted after the HIV self-test to discern opinions about the process and attitudes towards HIV self-testing in the future. The questions in the post-test survey were adapted from an earlier Australian study [33], with modifications made to reflect the local context and previous in-depth interviews conducted in MWPS about barriers and facilitators to 


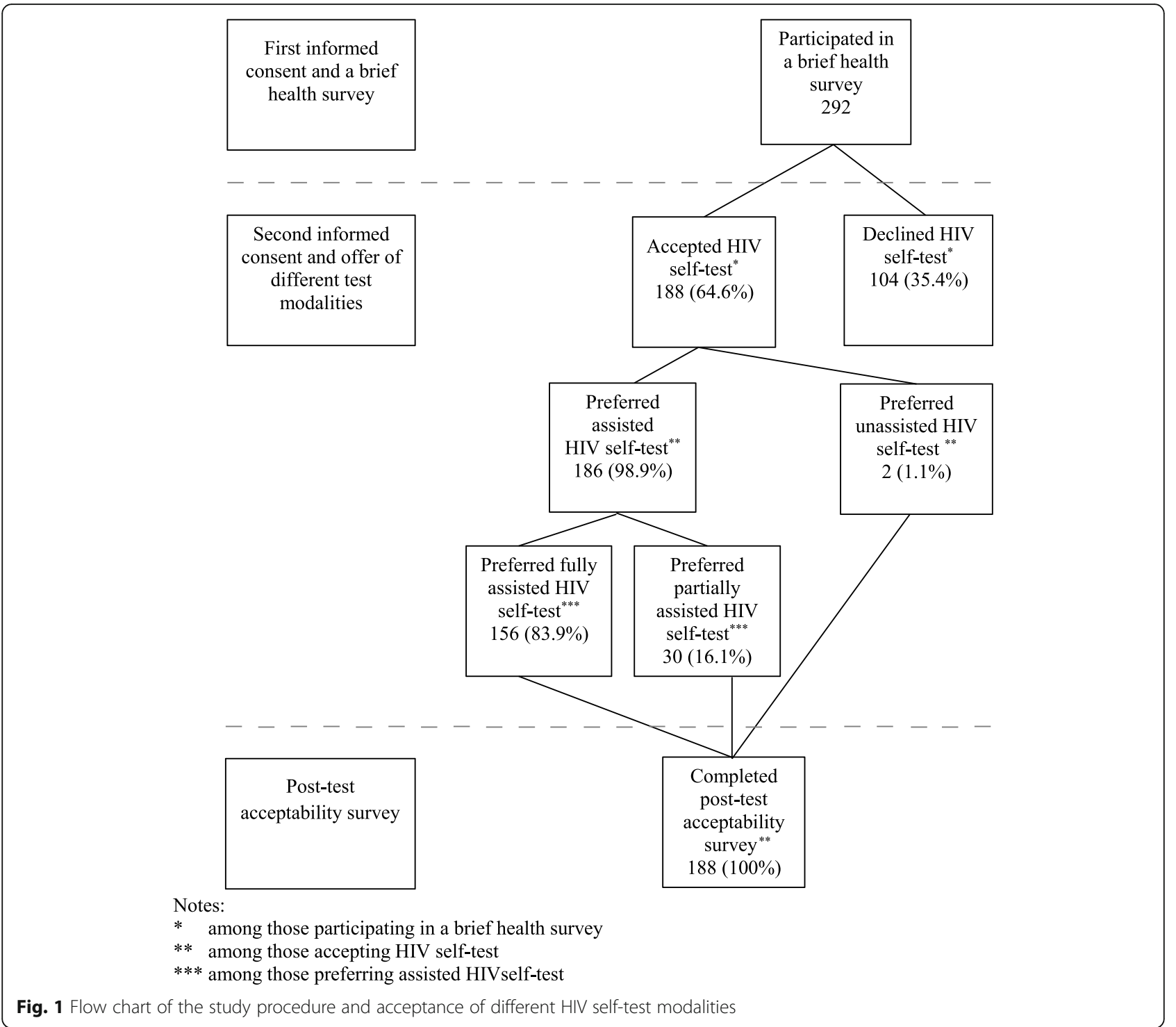

HIV testing [37]. The questionnaire included questions around what the men liked about HIV self-test, what they did not like about HIV self-test, how easy the test was, the likelihood of using HIV self-test in the future, the maximum they would be willing to pay for a HIV self-test.

Likert scale items were used to assess men's perception on ease of performance $(1=$ very difficult; $2=$ difficult; 3 = easy; 4 = very easy); and men's future willingness to purchase and use a HIV self-test ( 1 = very unlikely; 2 = unlikely; 3 = likely; 4 = very likely). The questionnaire was focus tested with ten lay workers and one pimp to confirm clarity of the questionnaire and feasibility of the HIV self-test and post-test survey procedures, with necessary changes made.

\section{Testing counselling and information}

Pre-test and post-test counselling were offered for all men who agreed to a HIV self-test. Vouchers contained a code to be able to link it with the survey data were distributed to the men to be taken to YKP clinic for a HIV confirmation test at the clinic. Further attempts were made by lay workers to follow up clients with potentially positive results as part of standard care.

\section{Analysis}

Analyses were conducted using STATA 14 (STATA Corporation, Texas, USA). The characteristics of the participants were analysed descriptively, using median and interquartile ranges (IQR), or frequency and percentages. Likert scale items were collapsed into 
categories: very difficult/difficult vs easy/very easy and likely/very likely vs unlikely/very unlikely. We calculated the acceptance of a HIV self-test, defined as the number of men who accepted a HIV self-test among those offered a HIV self-test by lay workers following the health survey. We also calculated the preference of the different test modalities (fully and partially assisted, and unassisted) defined as the number of men who preferred one of these options among those who accepted a HIV self-test. These outcomes were presented as the proportion with $95 \%$ confidence interval calculated.

Bivariate analysis was conducted using logistic regression, and further multivariate analysis using backward logistic regression was performed for data that was significant at less than 0.1 to identify factors associated with accepting a HIV self-test, and separately for preferring a fully assisted HIV self-test. In the multivariate analysis, only variables with the $p$-value of 0.05 were considered statistically associated with those two outcomes.

Among all participants involved in the brief health survey, we restricted the bivariate analysis of predictors of accepting a HIV self-test to participants with available data for all variables. Similarly, among all participants accepting HIV self-test, the bivariate analysis of factors associated with preferring a fully assisted HIV self-test was restricted to participants with available data for all variables. During this analysis, missing value categories for condom use during the last sexual contact with FSWs was created due to that this variable presents a high number of missing values. Ethnicity was selected as one of the covariates as in Indonesia there are around 1340 ethnic backgrounds [63], and other study has found the association between ethnicity and acceptability of HIV testing [64].

\section{Ethics approval}

Ethics approvals were obtained from the Research Ethics Committee of Udayana University/Sanglah Hospital, Indonesia and the Human Research Ethics Committees (HRECs) of the University of New South Wales, Australia.

As it was a pilot study only, we did not register it on a trial registry.

\section{Results}

\section{Characteristics of MWPS}

Around 70\% (292/417) of men who were approached for the health survey accepted to participate. The median age of the 292 men who participated in the health survey was 38.5 (IQR: 29.5-48) years. Just over a third of men (47.3\%) had completed at least senior high school, nearly half $(45.9 \%)$ were Javanese, $38 \%$ were Balinese and twothirds (76.4\%) had ever married. Men had a median number of 4 (IQR: 2-7) FSW sexual partners in the last 12 months. Around $59.7 \%$ of the men reported having used a condom at their last sexual encounter with a brothel-based FSW. Only $12.7 \%$ of the participants had ever been tested for HIV, with $5.8 \%$ of the men mentioned that they had been HIV tested in the last 12 months. Men cited multiple barriers to HIV testing at the clinic including embarrassment when asking for an HIV test (57.4\%), fear of being diagnosed with HIV (46.7\%), feeling healthy so not perceiving they needed a test (45.7\%), fear of having blood taken (42.6\%), distance from the clinic (34.6\%), embarrassment being seen at a clinic (31.1\%), anxiety waiting for the test results (31.8\%), lack of knowledge of where to go for testing (31.5\%), and concern over confidentiality (27\%) (Table 1), with $241(82.5 \%)$ men reported 2 or more barriers to HIV testing.

\section{Uptake and factors associated with different HIV self-test modalities}

Among the 292 respondents who completed the health survey, 188 (64.6\%; 95\%CI: 59.6-69.9\%) accepted a HIV self-test (see Fig. 1). Of these 188 men, $48.9 \%$ had completed at least senior high school, $47.3 \%$ were Javanese, $13.3 \%$ had ever been tested for HIV, with $6.4 \%$ of the men mentioned that they had been HIV tested in the last 12 months, and $58.9 \%$ reported condom use at their last sexual encounter with a FSW. (Table 1). Men were less likely to accept a HIV self-test if they stated feared being diagnosed with HIV as a barrier to HIV testing at the clinic (OR 0.4; 95\% CI 0.3-0.7; $p=0.001$ ). On the other hand, men were more likely to accept the HIV self-test if they mentioned feeling embarrassed to ask for an HIV test at the clinic as one of the barrier to testing (OR 1.8; 95\% CI 1.1-2.9; $p=0.030$ ). (Table 2).

Of the 188 men who accepted a HIV self-test, 186 (98.9\%; 95\% CI 96.2-99.9\%) preferred assisted and 2 (1.1\%; 95\% CI 0.1-3.8\%) unassisted. Of those who preferred assisted, 156 (83.9\%; 95\% CI 77.8-88.8\%) preferred to be fully assisted and 30 (16.1\%; 95\% CI $11.2-22.2 \%)$ partially assisted with unsupervised reading onsite. (Fig. 1).

There was only one factor associated with preference for a fully assisted HIV self-test, which was feeling anxious when waiting for HIV test results as a barrier to HIV testing at the clinic (OR 3.8; 95\% CI 1.3-11.3; $p=$ 0.018). (Table 3).

\section{HIV self-test outcomes}

Of the 188 men who accepted a HIV self-test and showed their result to the lay workers, there were 4 (2.1\%) reactive results (all preferred fully assisted), of whom 2 gave a history of previous HIV testing. For these 4 cases, there was no evidence of subsequent attendance 
Table 1 Socio-demographic characteristics, sexual behaviours, and HIV testing history of MWPS

\begin{tabular}{|c|c|c|}
\hline Characteristics of MWPS & $\begin{array}{l}\text { Participated in a } \\
\text { health survey } \\
\mathrm{n}(\%) \\
(\boldsymbol{N}=292)^{\wedge}\end{array}$ & $\begin{array}{l}\text { Accepted } \\
\text { HIV self-test } \\
n(\%) \\
(\mathbf{N}=188) \wedge \wedge\end{array}$ \\
\hline Median age (IQR) & $38.5(29.5-48)$ & $38(30-48)$ \\
\hline Had ever married & $223(76.4)$ & $140(74.5)$ \\
\hline \multicolumn{3}{|l|}{ Highest level of education } \\
\hline None/primary/junior high school & $154(52.7)$ & $96(51.1)$ \\
\hline Senior high school/TAFE/ degree & $138(47.3)$ & $92(48.9)$ \\
\hline \multicolumn{3}{|l|}{ Ethnicity } \\
\hline Balinese & $111(38)$ & $73(38.3)$ \\
\hline Javanese & $134(45.9)$ & $89(47.3)$ \\
\hline Other & $47(16.1)$ & $27(14.4)$ \\
\hline
\end{tabular}

Barriers to HIV testing at a clinic

Embarrassed to ask for an HIV test

$$
\text { No }
$$$$
\text { Yes }
$$

Fear of being diagnosed with HIV

$$
\text { No }
$$$$
\text { Yes }
$$

I am feeling healthy

$$
\text { No }
$$

Yes

Too afraid of having blood taken

$$
\text { No }
$$$$
\text { Yes }
$$

Embarrassed discussing sex life

$$
\text { No }
$$$$
\text { Yes }
$$

It's too far

$$
\text { No }
$$$$
\text { Yes }
$$

Embarrassed to be seen at the clinic

$$
\text { No }
$$

Yes

Anxious when waiting for results

No
Yes

I do not know where to go

$$
\text { No }
$$$$
\text { Yes }
$$

$123(42.6)$

$72(38.7)$

$166(57.4)$

$114(61.3)$

$154(53.3)$

$112(60.2)$

$135(46.7)$

$74(39.8)$

$157(54.3)$

$107(57.5)$

132 (45.7)

79 (42.5)

166 (57.4)

$108(58.1)$

123 (42.6)

78 (41.9)

$175(60.5)$

109 (58.6)

$114(39.5)$

77 (41.4)

$189(65.4)$

119 (64)

$100(34.6)$

67 (36)

\section{9 (68.9)}

$90(31.1)$

$130(69.9)$

56 (30.1)

197 (68.2)

$128(68.8)$

92 (31.8)

$58(31.2)$

198 (68.5)

$130(69.9)$

91 (31.5)

$56(30.1)$

I do not have time to go to the clinic

$$
\text { No }
$$

199 (68.9)

125 (67.2)

Yes

61 (32.8)
Table 1 Socio-demographic characteristics, sexual behaviours, and HIV testing history of MWPS (Continued)

\begin{tabular}{lll}
\hline Characteristics of MWPS & $\begin{array}{l}\text { Participated in a } \\
\text { health survey } \\
n(\%) \\
(\boldsymbol{N}=292) \wedge\end{array}$ & $\begin{array}{l}\text { Accepted } \\
\text { HIV self-test } \\
\mathrm{n}(\%) \\
(\boldsymbol{N}=188) \wedge \wedge\end{array}$ \\
\hline $\begin{array}{l}\text { Concern over confidentiality } \\
\text { No }\end{array}$ & $211(73)$ & $131(70.4)$ \\
Yes & $78(27)$ & $55(29.6)$ \\
Other & & \\
No & $283(97.9)$ & $181(97.3)$ \\
Yes & $6(2.1)$ & $5(2.7)$
\end{tabular}

Had ever been tested for HIV

No

$255(87.3) \quad 163(86.7)$

Yes

$37(12.7) \quad 25(13.3)$

Had been tested for HIV in the last 12 months

$\begin{array}{lll}\text { No } & 275(94.2) & 176(93.6) \\ \text { Yes } & 17(5.8) & 12(6.4)\end{array}$

Number of regular sexual partners* in the last year

\begin{tabular}{lll}
0 & $70(24)$ & $49(26.1)$ \\
1 or more & $222(76)$ & $139(73.9)$ \\
$\begin{array}{l}\text { Median number of casual sexual } \\
\text { partners in the last year (IQR) }\end{array}$ & $0(0-1)$ & $0(0-1)$ \\
$\begin{array}{l}\text { Median number of FSWs sexual } \\
\text { partners in last year (IQR) }\end{array}$ & $4(2-7)$ & $3(2-7)$ \\
$\begin{array}{l}\text { Median number of sex encounters } \\
\text { with FSWs in last year (IQR) }\end{array}$ & $6(2-12)$ & $6(2-12)$ \\
$\begin{array}{l}\text { Condom used at last sex with FSW } \\
\text { No }\end{array}$ & & \\
Yes & $100(40.3)$ & $65(41.1)$ \\
Location of the brothel visited & $148(59.7)$ & $93(58.9)$ \\
cluster 1 & & \\
cluster 2 & $59(20.2)$ & $42(22.3)$ \\
cluster 3 & $33(11.3)$ & $21(11.2)$ \\
cluster 4 & $26(8.9)$ & $16(8.5)$ \\
cluster 5 & $41(14)$ & $27(14.4)$ \\
cluster 6 & $24(8.2)$ & $17(9)$ \\
cluster 7 & $82(28.1)$ & $50(26.6)$ \\
\hline
\end{tabular}

*non-FSW

\# brothel-based

$\wedge$ Due to nonresponses on some items, columns may not sum to 292

$\wedge \wedge$ Due to nonresponses on some items, columns may not sum to 188

at the recommended referral HIV testing clinics at 2 months post HIV self-test.

Post-test survey

All the men who accepted a HIV self-test completed the post-test acceptability survey (188 respondents). In the post-test acceptability survey, the most 
Table 2 Bivariate and multivariate analysis of predictors of accepting a HIV self-test

\begin{tabular}{|c|c|c|c|c|c|c|}
\hline \multirow[t]{2}{*}{ Predictors } & \multirow[t]{2}{*}{$\begin{array}{l}\text { Total }(n) \\
(\boldsymbol{N}=288)\end{array}$} & \multirow[t]{2}{*}{$\begin{array}{l}\text { Accepted HIV self-test } \\
\mathrm{n}(\%)\end{array}$} & \multicolumn{2}{|c|}{$\begin{array}{l}\text { Bivariate analysis of predictors of } \\
\text { accepting a HIV self-test }\end{array}$} & \multicolumn{2}{|c|}{$\begin{array}{l}\text { Multivariate analysis of predictors of } \\
\text { accepting a HIV self-test }\end{array}$} \\
\hline & & & OR $(95 \% \mathrm{Cl})$ & $P$ value & OR $(95 \% \mathrm{Cl})$ & $P$ value \\
\hline \multicolumn{7}{|l|}{ Highest level of education } \\
\hline None/primary/junior high school & 153 & $95(62.1)$ & 1 & & & \\
\hline Senior high school/TAFE/ degree & 135 & $91(67.4)$ & $1.3(0.8-2.1)$ & 0.347 & & \\
\hline \multicolumn{7}{|l|}{ Ethnicity } \\
\hline Other & 46 & $27(58.7)$ & 1 & & & \\
\hline Balinese & 110 & $72(65.5)$ & $1.3(0.7-2.7)$ & 0.425 & & \\
\hline Javanese & 132 & $87(65.9)$ & $1.4(0.7-2.9)$ & 0.381 & & \\
\hline \multicolumn{7}{|l|}{ Had ever married } \\
\hline Yes & 222 & $139(62.6)$ & 1 & & & \\
\hline No & 66 & $47(71.2)$ & $1.5(0.8-2.7)$ & 0.201 & & \\
\hline \multicolumn{7}{|l|}{ Sexual behaviour } \\
\hline Number regular sexual partners ${ }^{*}$ last year & 288 & 186 & $0.8(0.5-1.2)$ & 0.214 & & \\
\hline Number casual sexual partners ${ }^{*}$ last year & 288 & 186 & $1.0(0.9-1.2)$ & 0.736 & & \\
\hline Number FSWs" sexual partners last year & 288 & 186 & $1.0(1.0-1.0)$ & 0.211 & & \\
\hline \multicolumn{7}{|l|}{ Condom use at last sex with FSWs ${ }^{\#}$} \\
\hline Yes & 145 & $92(63.5)$ & 1 & & & \\
\hline No & 99 & $64(64.7)$ & $1.1(0.6-1.8)$ & 0.848 & & \\
\hline Missing & 44 & $30(68.2)$ & $1.2(0.6-2.5)$ & 0.566 & & \\
\hline \multicolumn{7}{|l|}{ Had ever been tested for HIV } \\
\hline Yes & 34 & $23(67.7)$ & $1.2(0.5-2.5)$ & 0.691 & & \\
\hline No & 254 & $163(64.2)$ & 1 & & & \\
\hline \multicolumn{7}{|l|}{ Barriers to HIV testing at a clinic: } \\
\hline \multicolumn{7}{|l|}{ I do not know where to go } \\
\hline No & 197 & $130(66)$ & 1 & & & \\
\hline Yes & 91 & $56(61.5)$ & $0.8(0.5-1.4)$ & 0.463 & & \\
\hline \multicolumn{7}{|l|}{ I do not have time to go to the clinic } \\
\hline No & 198 & $125(63.1)$ & 1 & & & \\
\hline Yes & 90 & $61(67.8)$ & $1.2(0.7-2.1)$ & 0.445 & & \\
\hline \multicolumn{7}{|l|}{ It's too far } \\
\hline No & 188 & $119(63.3)$ & 1 & & & \\
\hline Yes & 100 & $67(67)$ & $1.2(0.7-2)$ & 0.532 & & \\
\hline \multicolumn{7}{|l|}{ Embarrassed discussing my sex life } \\
\hline No & 174 & $109(62.6)$ & 1 & & & \\
\hline Yes & 114 & $77(67.5)$ & $1.2(0.8-2)$ & 0.395 & & \\
\hline \multicolumn{7}{|l|}{ Embarrassed to ask for an HIV test } \\
\hline No & 122 & $72(59)$ & 1 & & 1 & \\
\hline Yes & 166 & $114(68.7)$ & $1.5(0.9-2.5)$ & 0.091 & $1.8(1.1-2.9)$ & 0.030 \\
\hline \multicolumn{7}{|l|}{ Anxious when waiting for results } \\
\hline No & 196 & $128(65.3)$ & 1 & & & \\
\hline Yes & 92 & $58(63)$ & $0.9(0.5-1.5)$ & 0.708 & & \\
\hline \multicolumn{7}{|l|}{ Embarrassed to be seen at clinic } \\
\hline No & 198 & $130(65.7)$ & 1 & & & \\
\hline Yes & 90 & $56(62.2)$ & $0.9(0.5-1.4)$ & 0.572 & & \\
\hline
\end{tabular}


Table 2 Bivariate and multivariate analysis of predictors of accepting a HIV self-test (Continued)

\begin{tabular}{|c|c|c|c|c|c|c|}
\hline \multirow[t]{2}{*}{ Predictors } & \multirow[t]{2}{*}{$\begin{array}{l}\text { Total (n) } \\
(\boldsymbol{N}=288)\end{array}$} & \multirow[t]{2}{*}{$\begin{array}{l}\text { Accepted HIV self-test } \\
\mathrm{n}(\%)\end{array}$} & \multicolumn{2}{|c|}{$\begin{array}{l}\text { Bivariate analysis of predictors of } \\
\text { accepting a HIV self-test }\end{array}$} & \multicolumn{2}{|c|}{$\begin{array}{l}\text { Multivariate analysis of predictors of } \\
\text { accepting a HIV self-test }\end{array}$} \\
\hline & & & OR (95\%Cl) & $P$ value & OR (95\%Cl) & $P$ value \\
\hline \multicolumn{7}{|c|}{ Concern over the confidentiality } \\
\hline No & 210 & $131(62.4)$ & 1 & & & \\
\hline Yes & 78 & $55(70.5)$ & $1.4(0.8-2.5)$ & 0.201 & & \\
\hline \multicolumn{7}{|c|}{ Too afraid of having blood taken } \\
\hline No & 166 & $108(65.1)$ & 1 & & & \\
\hline Yes & 122 & $78(63.9)$ & $1(0.6-1.6)$ & 0.844 & & \\
\hline \multicolumn{7}{|c|}{ Fear of being diagnosed with HIV } \\
\hline No & 154 & $112(72.7)$ & 1 & & 1 & \\
\hline Yes & 134 & $74(55.2)$ & $0.5(0.3-0.8)$ & 0.002 & $0.4(0.3-0.7)$ & 0.001 \\
\hline \multicolumn{7}{|c|}{ I am feeling healthy } \\
\hline No & 102 & $53(52)$ & 1 & & & \\
\hline Yes & 186 & $79(42.5)$ & $0.7(0.4-1.1)$ & 0.123 & & \\
\hline \multicolumn{7}{|c|}{ Location of the brothel } \\
\hline cluster 1 & 59 & $42(71.2)$ & 1 & & & \\
\hline cluster 2 & 33 & $21(63.6)$ & $0.7(0.3-1.8)$ & 0.456 & & \\
\hline cluster 3 & 25 & $15(61.5)$ & $0.6(0.2-1.6)$ & 0.318 & & \\
\hline cluster 4 & 40 & $27(67.5)$ & $0.8(0.4-2)$ & 0.695 & & \\
\hline cluster 5 & 23 & $17(70.8)$ & $1(0.4-3.4)$ & 0.805 & & \\
\hline cluster 6 & 81 & $49(61)$ & $0.6(0.3-1.3)$ & 0.192 & & \\
\hline cluster 7 & 27 & $15(55.6)$ & $0.5(0.2-1.3)$ & 0.158 & & \\
\hline
\end{tabular}

* non-FSW

\# Brothel-based

common responses in favour of HIV self-test were that men could test themselves and do so when they wanted, i.e. $89.8 \%$. Most men, i.e. $75.1 \%$, said there was nothing they did not like about the test. More than two-thirds of men, i.e. $77.6 \%$, said that they trusted the result a lot or completely, with $22.5 \%$ reporting little trust. The majority of men, i.e. $90.4 \%$, said it was likely or very likely that they would go to a doctor or clinic for further testing if they had a reactive HIV self-test result, including all men with a reactive HIV self-test result. (Table 4).

Also, among those completing the post-test acceptability survey (188 respondents), the majority of men indicated it would be likely or very likely they would test themselves (88.8\%), or other men after the study finished (91\%), and $63.3 \%$ would recommend a HIV self-test to partners. The places where men most often said they would like to purchase kits were chemists (88.8\%), facilities $(79.3 \%)$ or community organisations (70.7\%). (Table 5).

Nearly all, i.e. $97.3 \%$ men reported that it was easy for them to test themselves for HIV at brothels, and over 99\% reported each individual step was easy or very easy. Most respondents (93\%) said they would buy the kit at the price of IDR 50,000 (\$US 3.5) or below (data is not presented on the table).

\section{Discussion}

This study is the first to investigate the acceptance of HIV self-testing when offered to MWPS in brothels by lay health providers. Men attending brothels in Bali, Indonesia had a high level of acceptance of HIV self-test, with $64.6 \%$ of men offered an HIV self-test agreeing to have it. Nearly all preferred to be assisted when they conducted the self-test and of these, most preferred to be fully assisted consistent with the WHO definition, while $16.1 \%$ opted to be partially assisted which allowed them to read their results privately. Acceptability of the procedure was high, with most men reporting they liked the fact that they could test themselves, they found performing each step of the HIV self-test procedure easy and they were interested in future use. The level of HIV testing uptake achieved by offering a HIV self-test was around 6-7 times higher than current levels and findings from a past survey in 2015 in the same population in Bali [45] and 37 times higher than HIV testing rates among other high-risk men in Indonesia, 
Table 3 Bivariate and multivariate analysis of predictors of a fully assisted HIV self-test

\begin{tabular}{|c|c|c|c|c|c|c|}
\hline \multirow[t]{2}{*}{ Predictors } & \multirow[t]{2}{*}{$\begin{array}{l}\text { Total }(n) \\
(\boldsymbol{N}=186)\end{array}$} & \multirow{2}{*}{$\begin{array}{l}\text { Preferred fully } \\
\text { assisted HIV } \\
\text { self-test } \\
\mathrm{n}(\%)\end{array}$} & \multicolumn{2}{|c|}{$\begin{array}{l}\text { Bivariate analysis of } \\
\text { predictors of preferring a } \\
\text { fully assisted HIV self-test }\end{array}$} & \multicolumn{2}{|c|}{$\begin{array}{l}\text { Multivariate analysis of } \\
\text { predictors of preferring a } \\
\text { fully assisted HIV self-test }\end{array}$} \\
\hline & & & OR $(95 \% \mathrm{Cl})$ & $P$ value & $\mathrm{OR}(95 \% \mathrm{Cl})$ & $P$ value \\
\hline \multicolumn{7}{|l|}{ Highest level of education } \\
\hline None/primary/junior high school & 95 & $81(85.3)$ & 1 & & & \\
\hline Senior high school/TAFE/ degree & 91 & $73(80.2)$ & $0.7(0.3-1.5)$ & 0.364 & & \\
\hline \multicolumn{7}{|l|}{ Ethnicity } \\
\hline Other & 27 & $22(81.5)$ & 1 & & & \\
\hline Balinese & 72 & $62(86.1)$ & $1.4(0.4-4.6)$ & 0.568 & & \\
\hline Javanese & 87 & $70(80.5)$ & $1(0.3-2.8)$ & 0.906 & & \\
\hline \multicolumn{7}{|l|}{ Had ever married } \\
\hline Yes & 139 & $114(82)$ & 1 & & & \\
\hline No & 47 & $40(85.1)$ & $1.2(0.5-3.1)$ & 0.628 & & \\
\hline \multicolumn{7}{|l|}{ Sexual behaviour } \\
\hline Number regular sexual partners ${ }^{*}$ last year & 186 & 154 & $1.5(0.7-2.9)$ & 0.270 & & \\
\hline Number casual sexual partners ${ }^{*}$ last year & 186 & 154 & $0.8(0.6-1.2)$ & 0.250 & & \\
\hline Number FSWs" sexual partners last year & 186 & 154 & $1(1-1)$ & 0.319 & & \\
\hline \multicolumn{7}{|l|}{ Condom use at last sex with FSWs } \\
\hline Yes & 92 & $76(82.6)$ & 1 & & 1 & \\
\hline No & 64 & $58(90.6)$ & $2(0.8-5.5)$ & 0.163 & $1.8(0.7-5)$ & 0.257 \\
\hline Missing & 30 & $20(66.7)$ & $0.4(0.2-1.1)$ & 0.069 & $0.5(0.2-1.2)$ & 0.112 \\
\hline \multicolumn{7}{|l|}{ Had ever been tested for HIV } \\
\hline Yes & 23 & $17(74)$ & $0.5(0.2-1.5)$ & 0.234 & & \\
\hline No & 163 & $137(84.1)$ & 1 & & & \\
\hline \multicolumn{7}{|l|}{ Barriers to HIV testing at a clinic: } \\
\hline \multicolumn{7}{|l|}{ I do not know where to go } \\
\hline No & 130 & $103(79.2)$ & 1 & & 1 & \\
\hline Yes & 56 & $51(91.1)$ & $2.7(1-7.4)$ & 0.057 & $1.8(0.6-5.2)$ & 0.295 \\
\hline \multicolumn{7}{|l|}{ I do not have time to go to the clinic } \\
\hline No & 125 & $100(80)$ & 1 & & & \\
\hline Yes & 61 & $54(88.5)$ & $1.9(0.8-4.7)$ & 0.153 & & \\
\hline \multicolumn{7}{|l|}{ It's too far } \\
\hline No & 119 & $94(79)$ & 1 & & 1 & \\
\hline Yes & 67 & 60 (89.6) & $2.3(0.9-5.6)$ & 0.072 & $2.2(0.9-5.4)$ & 0.097 \\
\hline \multicolumn{7}{|l|}{ Embarrassed discussing my sex life } \\
\hline No & 109 & $90(82.6)$ & 1 & & & \\
\hline Yes & 77 & $64(83.1)$ & $1(0.5-2.3)$ & 0.922 & & \\
\hline \multicolumn{7}{|l|}{ Embarrassed to ask for an HIV test } \\
\hline No & 72 & $56(77.8)$ & 1 & & & \\
\hline Yes & 114 & $98(86)$ & $1.8(0.8-3.8)$ & 0.153 & & \\
\hline \multicolumn{7}{|l|}{ Anxious when waiting for results } \\
\hline No & 128 & $100(78.1)$ & 1 & & 1 & \\
\hline Yes & 58 & $54(93.1)$ & $3.8(1.3-11.3)$ & 0.018 & $3.8(1.3-11.3)$ & 0.018 \\
\hline
\end{tabular}


Table 3 Bivariate and multivariate analysis of predictors of a fully assisted HIV self-test (Continued)

\begin{tabular}{|c|c|c|c|c|c|c|}
\hline \multirow[t]{2}{*}{ Predictors } & \multirow[t]{2}{*}{$\begin{array}{l}\text { Total }(n) \\
(\boldsymbol{N}=186)\end{array}$} & \multirow{2}{*}{$\begin{array}{l}\text { Preferred fully } \\
\text { assisted HIV } \\
\text { self-test } \\
\text { n (\%) }\end{array}$} & \multicolumn{2}{|c|}{$\begin{array}{l}\text { Bivariate analysis of } \\
\text { predictors of preferring a } \\
\text { fully assisted HIV self-test }\end{array}$} & \multicolumn{2}{|c|}{$\begin{array}{l}\text { Multivariate analysis of } \\
\text { predictors of preferring a } \\
\text { fully assisted HIV self-test }\end{array}$} \\
\hline & & & OR $(95 \% \mathrm{Cl})$ & $P$ value & OR $(95 \% \mathrm{Cl})$ & $P$ value \\
\hline \multicolumn{7}{|c|}{ Embarrassed to be seen at clinic } \\
\hline No & 130 & $106(81.5)$ & 1 & & & \\
\hline Yes & 56 & $48(85.7)$ & $1.4(0.6-3.2)$ & 0.490 & & \\
\hline \multicolumn{7}{|c|}{ Concern over the confidentiality } \\
\hline No & 131 & $105(80.2)$ & 1 & & & \\
\hline Yes & 55 & $49(89.1)$ & $2(0.8-5.2)$ & 0.146 & & \\
\hline \multicolumn{7}{|c|}{ Too afraid of having blood taken } \\
\hline No & 108 & $86(79.6)$ & 1 & & & \\
\hline Yes & 78 & $68(87.2)$ & $1.7(0.8-3.9)$ & 0.182 & & \\
\hline \multicolumn{7}{|c|}{ Fear of being diagnosed with HIV } \\
\hline No & 112 & $88(78.6)$ & 1 & & 1 & \\
\hline Yes & 74 & $66(89.2)$ & $2.3(1-5.3)$ & 0.065 & $1.4(0.5-3.8)$ & 0.473 \\
\hline \multicolumn{7}{|c|}{ I am feeling healthy } \\
\hline No & 107 & $91(85.1)$ & 1 & & & \\
\hline Yes & 79 & $63(79.8)$ & $0.7(0.3-1.5)$ & 0.345 & & \\
\hline \multicolumn{7}{|c|}{ Location of the brothel } \\
\hline cluster 1 & 42 & $28(66.7)$ & 1 & & & \\
\hline cluster 2 & 21 & $21(100)$ & 1 & - & & \\
\hline cluster 3 & 15 & $13(80)$ & $2(0.5-8.3)$ & 0.338 & & \\
\hline cluster 4 & 27 & $27(100)$ & 1 & - & & \\
\hline cluster 5 & 17 & $17(100)$ & 1 & - & & \\
\hline cluster 6 & 49 & 40 (81.6) & $2.2(0.8-5.8)$ & 0.105 & & \\
\hline cluster 7 & 15 & $9(60)$ & $0.8(0.2-2.5)$ & 0.643 & & \\
\hline
\end{tabular}

* non-FSW

\# Brothel-based

including truck drivers, moto-taxi drivers, dockworkers and seafarers [44].

Understanding barriers (structural or attitudinal) to HIV testing at clinics, can inform the design of HIV self-testing programs. Our study demonstrated that offering a HIV self-test by a lay provider at the brothel seemed to overcome some of barriers raised by the men in the survey with regards to clinic-based HIV testing such as feeling embarrassed to ask for an HIV test at the clinic, embarrassment attending the clinic, afraid of having blood taken, and distance to clinic. Men were more likely to accept HIV self-test if they stated feeling embarrassed to ask for an HIV test at the clinic as one of the barrier to testing, which is inline with previous study conducted in this setting [48], and indicating the potential roles of HIV testing, as has been endorsed by WHO, to improve HIV testing access among those who are reluctant to visit the VCT clinics and ask for a HIV [25].

Men were less likely to accept HIV self-test if they feared being diagnosed with HIV, i.e. 55.2\% of men who reported a fear of being diagnosed with HIV were wiling to have a self-test, compared with $72.7 \%$ of men who did not report a fear. Fear of being diagnosed with HIV was also found to influence participant decisions in declining HIV self-test in a study in Cape Town [65]. It is likely that the fear of a HIV diagnosis was related to HIV stigma, which may be reduced by the ability of HIV self-test to normalise the testing procedure [66]. Efforts which help make the HIV self-testing more common and to alleviate HIV related stigma are thus paramount in this setting.

Most men preferred assisted HIV self-testing, even though the lay workers had minimal training, suggesting that lay providers could play an important role in HIV self-test models among MWPS in the future, as recommended in WHO's consolidated guidelines on HIV testing [25]. Although there are at least 6924 VCT clinics in Indonesia in 2019 [47], there are over 5 million MWPS, highlighting the importance of utilising other strategies to reach those who might be unable or unwilling to seek testing at the clinic [25]. Involving lay workers in HIV 
Table 4 Post-test acceptability survey findings on likes, dislikes about, and trust in HIV self-test among 188 respondents who accepted the HIV self-test

\begin{tabular}{|c|c|}
\hline Items & n (\%) \\
\hline \multicolumn{2}{|l|}{ What they liked about HIV self-testing } \\
\hline I could test myself & $168(89.8)$ \\
\hline Gives results in $20-40 \mathrm{~min}$ & $161(86.1)$ \\
\hline Convenient & $157(84)$ \\
\hline No need to go to the doctor or clinic & $157(84)$ \\
\hline No embarrassment & $140(74.9)$ \\
\hline Allows me to test when I want & $135(72.2)$ \\
\hline Does not require blood to be taken & $126(67.4)$ \\
\hline Confidential & $104(55.6)$ \\
\hline Saves time & $102(54.6)$ \\
\hline Opportunity to test partner(s) at the same time & $81(43.3)$ \\
\hline Others & $1(0.5)$ \\
\hline \multicolumn{2}{|l|}{ What they did not like about HIV self-testing } \\
\hline There was nothing I didn't like & $139(75.1)$ \\
\hline Concern over accuracy of the test & $19(10.3)$ \\
\hline $\begin{array}{l}\text { Not possible to have a full sexual health check } \\
\text { at the same time }\end{array}$ & $19(10.3)$ \\
\hline I don't like being tested at brothels & $14(7.6)$ \\
\hline Being supervised & $4(2.2)$ \\
\hline Waiting 20-40 min for results & $2(1.1)$ \\
\hline Difficult to perform & $1(0.5)$ \\
\hline Other & $1(0.5)$ \\
\hline \multicolumn{2}{|l|}{ Whether they trusted in the results } \\
\hline Not at all & $0(0)$ \\
\hline A little & $42(22.5)$ \\
\hline A lot & $140(74.9)$ \\
\hline Completely & $5(2.7)$ \\
\hline
\end{tabular}

Likelihood to go to clinic for further testing after a reactive HIV self-test result

UnlikelyNery unlikely

Likely/Nery likely

$170(90.4)$

prevention has reportedly led to substantial increases in the use of condoms use at brothel settings compared to a few decades ago [45]. The same success is possible for HIV self-test programs if support is provided for these lay workers.

The majority of men preferred fully assisted HIV selftesting with supervision during the reading of the test result. Men were more likely to prefer fully assisted HIV self-test if they reported anxiety when waiting for results as a barrier to HIV testing at the clinic, so the presence of someone assisting with the process may have overcome these concerns [67], particularly considering the majority of men had never HIV tested previously. The
Table 5 Post-test acceptability survey findings on likelihood of using a HIV self-test in the future among 188 respondents who accepted the HIV self-test

\begin{tabular}{lll}
\hline Likelihood to use HIV self-test in the future & $\begin{array}{l}\text { Unlikely/ } \\
\text { Very } \\
\text { Unlikely } \\
\mathrm{n}(\%)\end{array}$ & $\begin{array}{l}\text { Likely/ Very } \\
\text { likely } \\
\mathrm{n}(\%)\end{array}$ \\
\hline $\begin{array}{l}\text { Likelihood to use HIV self-tests in the future to: } \\
\text { Test yourself }\end{array}$ & $21(11.2)$ & $167(88.8)$ \\
Test a partner & $69(36.7)$ & $119(63.3)$ \\
Likelihood to recommend HIV self-tests & $17(9)$ & $171(91)$ \\
to other men & & \\
Likelihood to purchase HIV self-tests from: & $130(69.2)$ & $58(30.9)$ \\
Online/Internet & $21(11.2)$ & $167(88.8)$ \\
A chemist or pharmacy & $138(73.4)$ & $50(26.6)$ \\
A vending machine & $39(20.7)$ & $149(79.3)$ \\
A sexual health centre & $55(29.3)$ & $133(70.7)$ \\
A community organisation (e.g. YKP) & & \\
\hline
\end{tabular}

high acceptance of assisted HIV self-testing among firsttime testers has also been demonstrated in other studies such as those adolescents in Mozambique [68]. Two third of the participants in that study had never HIV tested previously, and over $75 \%$ of the participants chose directly assisted HIV self-testing [68]. The proportion requesting fully assisted testing might decrease as HIV self-testing becomes more common.

The analysis found very few associations between the questions asked and uptake of HIV self-test. The variables came from a brief health survey, and thus men were not asked about psychosocial or contextual factors related to their visit to the brothel that may have influenced their decision to have a self-testing. We deliberately kept the health survey brief and unrelated to self-testing to prevent the men from losing their interest in participating in the study. What the survey was able to show that ethnicity, age and sexual risk practices did not influence their decision to have a self-test, which is important information when scaling up the technology. We believe their willingness to have a selftest was related to convenience and privacy as demonstrated in our previous in-depth interviews [48].

The study highlighted a number of issues to consider for future HIV self-testing programs in MWPS in Indonesia. The first being the access points: nearly all men liked accessing HIV self-tests at brothels, but when asked about other potential ways, they cited a chemist as their preferred place to purchase a HIV self-test, consistent with long-standing practices in Indonesia and other Asia settings of self-purchasing medication for prevention and treatment of sexually transmitted infections [69, 70], and other treatments from pharmacies [71]. This might be due to the fact that sexually transmitted infections (STIs), including HIV, are highly stigmatised, 
and accessing health care through private pharmacies or street vendors provides easy access to a service with little fear of being interrogated with embarrassing questions [72]. Second, about a third of men reported 'little trust' in the results, suggesting the need for more community education about HIV self-tests and their accuracy. Third, although the majority of men (90.4\%) reported it was likely they would go to a doctor or clinic for further testing if they had a reactive HIV self-test result, in reality none of the four men with a reactive result attended for further testing at the recommended referral HIV testing clinic over a two-month follow-up period. Two of the four men had been tested in the past, but were not asked about the results of their past HIV test, so it is possible they already knew they had HIV infection, or were already in care [29], and did not feel the need to have another test at the clinic. It may also be that the four men did link outside the study clinic.

Linkage to care is a complex matter, and its measurement is challenging [73]. Various factors might also influence poor linkage, including stigma and the population being tested [73]. When scaling up HIV selftesting programmatically, strategies to improve linkage to care should be considered and evaluated such as phone calls, home visits from health care workers, including taking the confirmatory test to the home, and financial incentives [74-76].

With a program supported by the Bill \& Melinda Gates Foundation in 50 low- and middle-income countries, the cost of the OraQuick ${ }^{\circ}$ HIV self-test is now as low as US\$ 2 per test kit [77]. Given that most of the respondents in the current study also preferred the price of lower than $\$ 3.5$, the costs of self-tests needs to be considered if introducing HIV self-testing in this setting.

There are a few other limitations to consider also when interpreting the study findings, including that the data were collected via an interview rather than selfcompletion due to low education levels, and may be affected by social desirability bias [78, 79]. However, given the similarities of the findings with other studies, for example, the findings on previous testing rates and barriers to HIV testing, it may indicate otherwise. Also, participants of this study were recruited from brothel areas and might not be representative of all MWPS, particularly those who access non-brothel-based FSWs. Finally, the $2.1 \%$ HIV prevalence found in the current study may be an underestimation, as it is possible that some men visiting the brothels who were already HIV positive decided not to participate in the study; or an overestimation as we cannot rule out false positives. However, an overestimation is unlikely considering the high specificity of the test [80].

\section{Conclusions}

In conclusion, our study demonstrated that the majority of MWPS who were offered a HIV self-test by lay providers onsite at brothels would accept a HIV self-test, with most men preferring assisted to unassisted testing. HIV self-self test is not currently available free in the country. The high uptake of HIV self-test indicates its considerable potential to improve the rate of HIV testing among MWPS in Indonesia, either through lay workers' distribution at brothels or more broadly through purchasing through chemists as indicated in the survey, something that should be considered for HIV testing policy and programming in Indonesia. Future implementation research should assess the role of both lay workers at brothels and chemists in reaching MWPS in Indonesia, and consider novel strategies to improve and measure linkage to care. Future research should assess costs and the scalability of this model of HIV testing.

\section{Abbreviations}

FSW: Female sex worker; MWPS: Men who purchase sex; STIs: Sexually transmitted infections; VCT: Voluntary counselling and testing; YKP: Yayasan Kerti Praja; NGO: Non-government organization

\section{Acknowledgements}

We would like to thank Professor Dewa Nyoman Wirawan from Udayana University and Yayasan Kerti Praja for his valuable supports, all his input, and constructive feedback

\section{Authors' contributions}

LPLW involved in the conceptualization of the study, had major responsibility for the conduct of the study, developed and plan for analysis, conducted all statistical analysis, prepared the first draft of this manuscript and coordinated revisions. JK and RG supervised LPLW throughout study design, data collection, data analysis and preparation of the manuscript, involved in the conceptualization of the study, funding acquisition, and review \& editing the final draft. All authors read and approved the final version of the manuscript.

\section{Funding}

The study is funded by a National Health and Medical Research Council (NHMRC) Program Grant \# APP1071269. The contents of the published material are solely the responsibility of the administering institution, a participating institution or individual authors and do not reflect the views of the NHMRC. The funding source had no role in the design of the study, and was not involved in data collection, data analysis, interpretation of the results, or writing of the manuscript.

\section{Availability of data and materials}

The dataset generated and/or analysed in the current study is not publicly available due to it contains potentially sensitive information. Requests for the data may be sent to Luh Putu Lila Wulandari (putuwulandari@gmail.com, or Iwulandari@kirby.unsw.edu.au).

\section{Ethics approval and consent to participate}

Ethics approvals were obtained from the Research Ethics Committee of Udayana University/Sanglah Hospital, Indonesia and the Human Research Ethics Committees (HRECs) of the University of New South Wales, Australia. All participants gave written informed consent to participate in the study.

\section{Consent for publication}

Not applicable.

Competing interests

None declared. 
Received: 16 July 2019 Accepted: 29 April 2020

Published online: 19 May 2020

\section{References}

1. Carael M, Slaymaker E, Lyerla R, Sarkar S. Clients of sex workers in different regions of the world: hard to count. Sexually Transmitted Infections. 2006; 82(Suppl 3):iii26-iii33.

2. Baral S, Beyrer C, Muessig K, Poteat T, Wirtz AL, Decker M, et al. Burden of HIV among female sex workers in low-income and middle-income countries: a systematic review and meta-analysis. Lancet Infect Dis. 2012; 12(7):538-49.

3. Prüss-Ustün A, Wolf J, Driscoll T, Degenhardt L, Neira M, Calleja JMG. HIV due to female sex work: regional and global estimates. PLoS One. 2013;8(5): e63476.

4. UNAIDS. UNAIDS data 2019. UNAIDS; 2019.

5. UNAIDS. Global AIDS update 2019 - communities at the Centre. Geneva, Switzerland: UNAIDS; 2019.

6. Alary M, Lowndes CM, Mukenge-Tshibaka L, Gnintoungbe CA, Bedard E, Geraldo N, et al. Sexually transmitted infections in male clients of female sex workers in Benin: risk factors and reassessment of the leucocyte esterase dipstick for screening of urethral infections. Sex Transm Infect. 2003;79(5): 388-92.

7. Choudhry V, Ambresin AE, Nyakato VN, Agardh A. Transactional sex and HIV risks - evidence from a cross-sectional national survey among young people in Uganda. Global Health Action. 2015;8(27249).

8. Gomes do Espirito Santo ME, Etheredge GD. HIV prevalence and sexual behaviour of male clients of brothels' prostitutes in Dakar, Senegal. AIDS Care. 2003;15(1):53-62.

9. Lowndes CM, Alary M, Gnintoungbe CA, Bedard E, Mukenge L, Geraldo N, et al. Management of sexually transmitted diseases and HIV prevention in men at high risk: targeting clients and non-paying sexual partners of female sex workers in Benin. AIDS. 2000;14(16):2523-34.

10. Sabido M, Lahuerta M, Hernandez G, Montoliu A, Gonzalez V, Giardina F, et al. HIV, sexually transmitted infections, and risk behaviours among clients of sex workers in Guatemala - are they a bridge in HIV transmission? Sex Transm Infect. 2011:87:A125.

11. Cowan FM, Langhaug LF, Hargrove JW, Jaffar S, Mhuriyengwe L, Swarthout TD, et al. Is sexual contact with sex workers important in driving the HIV epidemic among men in rural Zimbabwe? J Acquir Immune Defic Syndr. 2005;40(3):371.

12. Shaw S, Deering K, Reza-Paul S, Isac S, Ramesh B, Washington R, et al, Prevalence of HIV and sexually transmitted infections among clients of female sex workers in Karnataka, India: a cross-sectional study. BMC Public Health. 2011;11(Suppl 6):S4.

13. Reilly KH, Wang J, Zhu Z, Li SC, Yang T, Ding G, et al. HIV and associated risk factors among male clients of female sex workers in a Chinese border region. Sex Transm Dis. 2012;39(10):750.

14. Shaw SY, Bhattacharjee $P$, Isac $S$, Deering KN, Ramesh BM, Washington $R$, et al. A cross-sectional study of sexually transmitted pathogen prevalence and condom use with commercial and noncommercial sex partners among clients of female sex workers in southern India. Sex Transm Dis. 2013;40(6): 482-9.

15. Nadol P, Hoang TV, Le L, Nguyen TA, Kaldor J, Law M. High HIV prevalence and risk among male clients of female sex workers in Hanoi and Ho Chi Minh City. Vietnam AIDS and Behavior. 2017:1-13.

16. WHO/UNICEF/UNAIDS. Progress report 2011: Global HIV/AIDS response: Epidemic update and health sector progress towards universal access 2011.

17. Li C, Jenny HH, Xinghua W, Zhiyong S, Huaxiang L, Huanhuan C, et al. Disparities in HIV and syphilis prevalence and risk factors between older male clients with and without steady sex partners in southwestern rural China. BMC Infect Dis. 2017;17(1):1-7.

18. Pan SM, Parish WL, Huang YY. Clients of female sex workers: a populationbased survey of China. J Infect Dis. 2011;204(Suppl. 5):S1211-S7.

19. Bunnell R, Opio A, Musinguzi J, Kirungi W, Ekwaru P, Mishra V, et al. HIV transmission risk behavior among HIV-infected adults in Uganda: results of a nationally representative survey. AIDS. 2008;22.

20. The INSIGHT START Study Group. Initiation of antiretroviral therapy in early asymptomatic HIV infection. N Engl J Med. 2015;373(9):795-807.

21. Donnell D, Baeten JM, Kiarie J, Thomas KK, Stevens W, Cohen CR, et al. Heterosexual HIV-1 transmission after initiation of antiretroviral therapy: a prospective cohort analysis. Lancet. 2010;375(9731):2092-8.
22. Rodger AJ, Cambiano V, Bruun T, Vernazza P, Collins S, Degen O, et al. Risk of HIV transmission through condomless sex in serodifferent gay couples with the HIV-positive PARTNER taking suppressive antiretroviral therapy (PARTNER): final results of a multicentre, prospective, observational study. Lancet. 2019.

23. UNAIDS. 90-90-90 An ambitious treatment target to help end the AIDS epidemic: UNAIDS; 2014 [cited 20186 March]. Available from: http://www. unaids.org/sites/default/files/media_asset/90-90-90_en.pdf.

24. UNAIDS. Ambitious treatment targets: writing the final chapter of the AIDS epidemic. Geneva 2014.

25. World Health Organisation. Consolidated guidelines on HIV testing services. 2015.

26. World Health Organisation. Guidelines on HIV self-testing and partner notification: supplement to consolidated guidelines on HIV testing services. Geneva: World Health Organisation; 2016.

27. Linas BP. Potential impact and cost-effectiveness of self-testing for HIV in low-income countries. J Infect Dis. 2015;212(4):513-5.

28. Krause J, Subklew-Sehume F, Kenyon C, Colebunders R. Acceptability of HIV self-testing: a systematic literature review. BMC Public Health. 2013;13(1):735.

29. Johnson CC, Kennedy C, Fonner V, Siegfried N, Figueroa C, Dalal S, et al. Examining the effects of HIV self-testing compared to standard HIV testing services: a systematic review and meta-analysis. Journal of the International AIDS Society. 2017;20(1):n/a-n/a.

30. Oldenburg CE, Biello KB, Perez-Brumer AG, Rosenberger J, Novak DS, Mayer KH, et al. HIV testing practices and the potential role of HIV self-testing among men who have sex with men in Mexico. Int J STD AIDS. 2017;28(3):242-9.

31. Sharma M, Ying R, Tarr G, Barnabas R. Systematic review and meta-analysis of community and facility-based HIV testing to address linkage to care gaps in sub-Saharan Africa. Nature. 2015;528:S77.

32. Celum C, Barnabas R. Reaching the 90-90-90 target: lessons from HIV selftesting. Lancet HIV. 2019;6(2):e68-e9.

33. Jamil MS, Prestage G, Fairley CK, Grulich AE, Smith KS, Chen M, et al. Effect of availability of HIV self-testing on HIV testing frequency in gay and bisexual men at high risk of infection (FORTH): a waiting-list randomised controlled trial. Lancet HIV. 2017.

34. Ngure K, Heffron R, Mugo N, Thomson KA, Irungu E, Njuguna N, et al. Feasibility and acceptability of HIV self-testing among pre-exposure prophylaxis users in Kenya. J Int AIDS Soc. 2017;20(1):21234.

35. Pai N, Sharma J, Shivkumar S, Pillay S, Vadnais C, Joseph L, et al. Supervised and unsupervised self-testing for HIV in high- and low-risk populations: a systematic review. PLoS Medicine. 2013;10(4).

36. Stevens DR, Vrana CJ, Dlin RE, Korte JE. A global review of HIV self-testing: themes and implications. AIDS Behav. 2017:1-16.

37. Wulandari LPL, Kaldor J, Januraga PP. Low HIV testing rate among men who purchase sex (MWPS) in Bali, Indonesia, and predictors of it. 2017 Australasian HIV \& AIDS Conference Joint with 2017 Australasian Sexual Health Conference Canberra 2017.

38. Flowers P, Riddell J, Park C, Ahmed B, Young I, Frankis J, et al. Preparedness for use of the rapid result HIV self-test by gay men and other men who have sex with men (MSM): a mixed methods exploratory study among MSM and those involved in HIV prevention and care. HIV Medicine. 2017;18(4):245-55.

39. Volk JE, Lippman SA, Grinsztejn B, Lama JR, Fernandes NM, Gonzales P, et al. Acceptability and feasibility of HIV self-testing among men who have sex with men in Peru and Brazil. Int J STD AIDS. 2016;27(7):531-6.

40. World Health Organisation. Consolidated guidelines on HIV prevention, diagnosis, treatment and care for key populations. World Health Organisation; 2014.

41. Wirtz AL, Clouse E, Veronese V, Thu KH, Naing S, Baral SD, et al. New HIV testing technologies in the context of a concentrated epidemic and evolving HIV prevention: qualitative research on HIV self-testing among men who have sex with men and transgender women in Yangon, Myanmar. J Int AIDS Soc. 2017;20(1):21796.

42. UNAIDS. HIV prevalence : male adults (15-49). UNAIDS; 2019.

43. Indonesian Ministry of Health. Estimates of the size of key populations at risk for HIV infection in Indonesia in 2016 (Estimasi jumlah populasi kunci HIV di Indonesia 2016). Jakarta: Indonesian Ministry of Health; 2017.

44. Indonesian Ministry of Health. Integrated biological and Behavioural survey (IBBS) 2015. Jakarta, Indonesia: Indonesian Ministry of Health; 2016.

45. Wulandari LPL, Kaldor J, Januraga PP. High condom use but low HIV testing uptake reported by men who purchase sex in Bali. Indonesia Aids Care. 2018;30(10):1215-22. 
46. Indonesian Ministry of Health. Indonesia Intergrated biological and Behavioural survey (IBBS) 2011. Jakarta: Indonesian Ministry of Health; 2011.

47. Indonesian Ministry of Health. Trend in the reported cases of HIV AIDS and STIs, second trimester 2019. Jakarta, Indonesia: Indonesian Ministry of Health; 2019.

48. Wulandari LPL, Ruddick A, Guy R, Kaldor J. "Self-testing sounds more private, rather than going to the clinic and everybody will find out": facilitators and barriers regarding HIV testing among men who purchase sex in Bali, Indonesia. PloS One. 2019;https://doi.org/10.1371/journal.pone.0214987.

49. Chanda MM, Ortblad KF, Mwale M, Chongo S, Kanchele C, Kamungoma N, et al. HIV self-testing among female sex workers in Zambia: a cluster randomized controlled trial. PLoS Med. 2017;14(11):e1002442.

50. Mavedzenge S, Sibanda E, Dirawo J, Hatzold K, Mugurungi O, Cowan F. Feasibility of HIV self-test programming among female sex workers in Zimbabwe. IAS 2017; Paris 2017.

51. Kelvin EA, George G, Mwai E, Kinyanjui S, Romo ML, Odhiambo JO, et al. A randomized controlled trial to increase HIV testing demand among female sex workers in Kenya through announcing the availability of HIV self-testing via text message. AIDS and Behavior. 2018.

52. Tun W, Vu L, Dirisu O, Sekoni A, Shoyemi E, Njab J, et al. Uptake of HIV selftesting and linkage to treatment among men who have sex with men (MSM) in Nigeria: a pilot programme using key opinion leaders to reach MSM. J Int AIDS Soc. 2018;21(S5):e25124.

53. Wray TB, Chan PA, Simpanen E, Operario D. A pilot, randomized controlled trial of HIV self-testing and real-time post-test counseling/referral on screening and preventative care among men who have sex with men. AIDS Patient Care STDs. 2018;32(9):360-7.

54. Thirumurthy H, Masters SH, Mavedzenge SN, Maman S, Omanga E, Agot K. Promoting male partner HIV testing and safer sexual decision making through secondary distribution of self-tests by HIV-negative female sex workers and women receiving antenatal and post-partum care in Kenya: a cohort study. Lancet HIV. 2016;3(6):e266-e74.

55. Asiimwe S, Oloya J, Song X, Whalen CC. Accuracy of un-supervised versus provider-supervised self-administered HIV testing in Uganda: a randomized implementation trial. AIDS Behav. 2014;18(12):2477-84.

56. Burke VM, Nakyanjo N, Ddaaki W, Payne C, Hutchinson N, Wawer MJ, et al. HIV self-testing values and preferences among sex workers, fishermen, and mainland community members in Rakai, Uganda: a qualitative study. PLoS One. 2017;12(8):e0183280.

57. Kelvin EA, George G, Mwai E, Nyaga EN, Mantell JE, Romo ML, et al. Offering self-administered oral HIV testing as a choice to truck drivers in Kenya: predictors of uptake and need for guidance while self-testing. AIDS Behav. 2018;22(2):580-92.

58. Strauss M, George G, Lansdell E, Mantell JE, Govender K, Romo M, et al. HIV testing preferences among long distance truck drivers in Kenya: a discrete choice experiment. AIDS Care. 2018;30(1):72-80.

59. Eldridge SM, Chan CL, Campbell MJ, Bond CM, Hopewell S, Thabane L, et al. CONSORT 2010 statement: extension to randomised pilot and feasibility trials. BMJ. 2016;355:15239.

60. Indonesian Ministry of Health. Trend in reported cases of HIV AIDS and STIS, first trimester 2019. Jakarta, Indonesia: Indonesian Ministry of Health; 2019.

61. Kerti Praja Foundation. Rencana sampling survey pelanggan PSP Bali (Planning of sampling procedure for survey on clients of sex workers in Bali). 2015.

62. Wirawan DN. Trends in HIV prevalence, condom use and associated factors among female sex workers in Denpasar, Bali, Indonesia. Public Health and Preventive Medicine Archive. 2014;2(1).

63. The Indonesian Government. Suku Bangsa (Ethnicity) 2019 [Available from: https://www.indonesia.go.id/profil/suku-bangsa.

64. Swenson RR, Hadley WS, Houck CD, Dance SK, Brown LK. Who accepts a rapid HIV antibody test? The role of race/ethnicity and HIV risk behavior among community adolescents. J Adolesc Health. 2011;48(5):527-9.

65. Martínez Pérez G, Cox V, Ellman T, Moore A, Patten G, Shroufi A, et al. 'I know that I do have HIV but nobody saw me': oral HIV self-testing in an informal settlement in South Africa. PloS One. 2016;11(4):e0152653.

66. Makusha T, Knight L, Taegtmeyer M, Tulloch O, Davids A, Lim J, et al. HIV self-testing could "revolutionize testing in South Africa, but it has got to be done properly": Perceptions of key stakeholders. PLoS One. 2015;10(3).

67. Lippman SA, Moran L, Sevelius J, Castillo LS, Ventura A, Treves-Kagan S, et al. Acceptability and feasibility of HIV self-testing among transgender women in San Francisco: a mixed methods pilot study. AIDS Behav. 2016; 20(4):928-38.

68. Hector J, Davies M-A, Dekker-Boersema J, Aly MM, Abdalad CCA, Langa EBR, et al. Acceptability and performance of a directly assisted oral HIV selftesting intervention in adolescents in rural Mozambique. PLoS One. 2018; 13(4):e0195391.

69. Fajans P, Ford K, Wirawan DN. AIDS knowledge and risk behaviors among domestic clients of female sex workers in Bali, Indonesia. Soc Sci Med. 1995; 41(3):409-17.

70. Fajans P, Wirawan DN, Ford K. STD knowledge and behaviours among clients of female sex workers in Bali, Indonesia. AIDS Care. 1994;6(4):459-75.

71. Leng Bun $H$, Detels $R$, Heng $S$, Mun P. The role of sex worker clients in transmission of HIV in Cambodia. Int J STD AIDS. 2005;16(2):170-4.

72. Msiska R, Nangawe E, Mulenga D, Sichone M, Kamanga J, Kwapa P. Understanding lay perspectives: care options for STD treatment in Lusaka. Zambia Health Policy and Planning. 1997;12(3):248.

73. Neuman M, Taegtmeyer M, Hatzold K, Johnson CC, Weiss HA, Fielding K Challenges in measurement of linkage following HIV self-testing: examples from the STAR project. J Int AIDS Soc. 2019;22(S1):e25238.

74. d'Elbee M, Indravudh PP, Mwenge L, Kumwenda MM, Simwinga M, Choko AT, et al. Preferences for linkage to HIV care services following a reactive self-test: discrete choice experiments in Malawi and Zambia. AIDS. 2018; 32(14):2043-9.

75. Chipungu J, Bosomprah S, Zanolini A, Thimurthy H, Chilengi R, Sharma A, et al. Understanding linkage to care with HIV self-test approach in Lusaka, Zambia - a mixed method approach. PLoS One. 2017;12(11):e0187998.

76. Choko AT, Corbett EL, Stallard N, Maheswaran H, Lepine A, Johnson CC, et al. HIV self-testing alone or with additional interventions, including financial incentives, and linkage to care or prevention among male partners of antenatal care clinic attendees in Malawi: an adaptive multi-arm, multistage cluster randomised trial. PLoS Med. 2019;16(1):e1002719.

77. OraSure Technologies Inc. What is the Bill and Melinda Gates Foundation agreement with OraSure Technologies? 2017.

78. Schick V, Calabrese SK, Herbenick D. Survey methods in sexuality research: American Psychological Association; 2014. 81 p.

79. Difranceisco W, McAuliffe TL, Sikkema KJ. Influences of survey instrument format and social desirability on the reliability of self-reported high risk sexual behavior. AIDS Behav. 1998;2(4):329-37.

80. Figueroa C, Johnson C, Ford N, Sands A, Dalal S, Meurant R, et al. Reliability of HIV rapid diagnostic tests for self-testing compared with testing by health-care workers: a systematic review and meta-analysis. Lancet HIV. 2018;5(6):e277-e90.

\section{Publisher's Note}

Springer Nature remains neutral with regard to jurisdictional claims in published maps and institutional affiliations.
Ready to submit your research? Choose BMC and benefit from:

- fast, convenient online submission

- thorough peer review by experienced researchers in your field

- rapid publication on acceptance

- support for research data, including large and complex data types

- gold Open Access which fosters wider collaboration and increased citations

- maximum visibility for your research: over $100 \mathrm{M}$ website views per year

At BMC, research is always in progress.

Learn more biomedcentral.com/submissions 